\title{
Influence of Integrated Nutrient Management Strategies on Soil Fertility
}

\author{
Amit Kumar Pandey, Ashutosh Singh* and Umesh Singh \\ Mandan Bharti Agriculture College, Agwanpur, Saharsa, Bihar (India) \\ *Corresponding author
}

\section{A B S T R A C T}

Keywords

A Integrated nutrient management, Soil Fertility, Strategy

Article Info

Accepted:

20 July 2020

Available Online:

10 August 2020
Soil fertility management by integrated nutrient management is getting support to overcome the problems faced by chemical fertilizers, like soil pollution, nutrient leaching, and over dependent of costly external inputs. An organic fertilizer improves physical and microbiological properties of soil but they have comparatively low in nutrient content, so larger quantity is required for plant growth. However, inorganic fertilizers are usually immediately and fast containing all necessary macro and micro nutrients that are directly accessible for plants. But continuous use of chemical fertilizers alone causes soil organic matter degradation, soil acidity and environment pollution. So, replacement of a part of chemical fertilizers by organic manure through a simple technique of using minimum effective dose of sufficient and balanced quantities of organic and inorganic fertilizers in combination with specific microorganisms called integrated nutrient management has a bright solution in this area. Eco-friendly approach integrated nutrient management occurring a balance between fertilizers input and crop nutrient requirement and maintain the soil fertility is reviewed with regard to sustainable agriculture.

\section{Introduction}

Global food production needs to be increased at least by $70 \%$ over the current level by 2050 to meet the increase in food demand, which rapidly increases as a result of over pollution. To achieve this challenging target, agriculture must grow significantly, in consideration of the factors that contribute to increase the yield production, which are already reduced or tend to reduce, since they are placing unprecedented pressure on the natural resources. Intensive cropping system with high yielding varieties for boosting food production caused marked depletion of inherent nutrient reserves in soil. Consequently along with deficiency of $\mathrm{N}, \mathrm{P}$ and $\mathrm{K}$ the deficiency of secondary and micronutrients are frequently reported. Presently, the major concern in agriculture is to arrest any further decline in crop productivity and soil quality. Although high 
yielding nutrient responsive crop varieties resulted in higher productivity, it led to the over explanation soil reserves and other resources. In general, Indian soils are poor in fertility, as these have been consistently depleted of their finite nutrient resources due to continuous cultivation for centuries, adoption of modern agricultural technology and imbalanced use of fertilizers and poor use efficiency of fertilizers.

Currently, our goal of interest need to be modified in managing nutrient programme to provide a safe food supply free from pollutants or at least which contains a minimum level of agrochemicals contaminants further more guaranteeing an environment with pollution. Therefore, the great challenges have been to optimizes the nutrient supplies to maintain high nutrient use efficiency, refine the natural resources, modify the agricultural practices to achieve more grain yield per unit area, without jeopardizing the soil and natural resources and improve the water use efficiency to provide more crop per drop. All of these are the most important goals, which can be achieved by the implementation of integrated nutrient management programme not only at the present time but also in the near future. The objective of the present review is to assess the effect of integrated nutrient management strategies and their contribution to soil fertility.

\section{Results of the integrated nutrient management on soil fertility}

\section{Soil organic carbon}

Continuous cropping without the application of organic manure caused a decrease in organic carbon (Nambiar, 1985). Singh et al., (1999) working on mollisols at Pantnagar reported that 10 years of continuous intensive rice-wheat cropping under various fertilizers and manure treatment recorded drastic reduction in organic matter except in lot receiving single super phosphate and FYM. Beri et al., (1995) reported that maximum increase in soil organic carbon content was observed with integrated use of inorganic fertilizers $(\mathrm{N}+\mathrm{P}+\mathrm{K})$ and organic manures. Continuous application of fertilizers alone or in combination with graded level of FYM for soybean based cropping system was studied by Babhublkar et al., (2000) and reported that highest organic carbon status due to application of higher rate of FYM with half dose of $\mathrm{N}$ and $\mathrm{P}$ fertilizers.

Organic carbon content increased significantly $\left(6-80 \mathrm{~g} \mathrm{~kg}^{-1}\right)$ in cultivated soil over uncultivated soil $\left(5-19 \mathrm{~g} \mathrm{~kg}^{-1}\right)$ under the long term of different cropping system (Sharma and Bali, 2000). Singh and Swarup (2000) assess the result of long term fertilizers experiment in various agro-ecological regions of India and observed a decline in organic carbon as a result of the continuous application of $\mathrm{N}$ fertilizers a alone while the balanced use of chemical fertilizers along with organic manure improved organic carbon. Focusing on role of soil organic carbon in maintaining soil fertility and productivity. Yaduvanshi (2001) reported that continuous use of inorganic fertilizers reduced the organic carbon content of soil.

The addition of FYM and integrated use of FYM with chemical fertilizers resulted in significantly higher organic carbon accumulation over inorganic fertilizers alone after harvest of maize in an alfisols (Kumari et al., 2013). Ravankar et al., (2005) reported that the maximum amount of organic carbon was found in the plot receiving inorganic fertilizer in combination with organics. Working on use of organic manures and fertilizers in rice-wheat cropping system. Kumar and Yadav (2003) noted an increase in organic matter content and it was attributed to 
the direct incorporation of organic matter, better root growth and more plant residue addition.

The effect of integrated use of chemical fertilizers and FYM in long term fertilizers experiment in all the treatments, the organic carbon content increased however, a marginal decrease was registered in the $100 \% \mathrm{~N}$ and control plot Sharma and Subehia (2003). Highest organic carbon content in FYM and green manure plots than in the control plots under rice-wheat cropping system in Haryana was also reported by Phogat et al., (2004). Gathala et al., (2007) assess the effect of integrated nutrient management in soil properties in the long term fertilizers experiment noted an increase in organic matter content. Singh and Nepalia (2009) conducted an experiment at Rajasthan college of Agriculture, Udaipur, Rajasthan and concluded that application of vermicompost @ $5 \mathrm{t} \mathrm{ha}^{-1}$ with $100 \% \mathrm{RDF}$ on maize improved the organic carbon content of soil than control. Pandey et al., (2009) reported that addition of different organic materials increased the organic carbon of the soil.

Highest organic carbon content (0-88\%) was observed in the treatment where $4 \mathrm{t} \mathrm{ha}^{-1}$ organic manure was applied along with recommended level of NPK and $\mathrm{Zn}$ at $0.5 \mathrm{~kg}$ ha $^{-1}$ (Sur et al., 2010). The effects of different integrated nutrient management practices on soil organic carbon as well as the sustainability of the rice-wheat system were evaluated in long term experiment at different agro-climatic zone of IGP by Nayak and Mohan (2012). They reported that application of NPK either through inorganic fertilizers or through combination of inorganic fertilizers and organics such as FYM or crop residue or green manure improved the soil organic carbon content. Karmakar et al., (2011) reported that the application of 50\% NPK, $23 \% \mathrm{~N}$ through FYM, green manure and blue green algae increased the organic carbon status of soil. Organic carbon wad recorded maximum in integrated nutrient management treatment including vermicompost and recommended dose of NPK (Lalith Kannan et al., 2013). Highest organic content with the application of RDF (120:60:40 NPK kg ha ${ }^{-1}$ ) + FYM $10 \mathrm{t} \mathrm{ha}^{-1}$ was also reported by Pandey and Awasthi (2014). The result of the field experiment concluded by Sarkar et al., (2016) at Nadia West Bengal revealed that the amount of organic carbon in soil was found to maintain the highest fertility status in the treatment receiving NPK + FYM $10 \mathrm{t} \mathrm{ha}^{-1}+$ Zn $5 \mathrm{~kg} \mathrm{ha}^{-1}$.

The treatment with organic nutrient management package registered significant increase in soil organic carbon (24.4 to $41.9 \%$ ) and the build up was maximum in the soil applied with one third $\mathrm{N}$ each through FYM, green manuring and neem oil cake + Azospirillum + PSB to rice (Patra et al., 2017). Organic carbon content of soil after harvest of pearl millet increased significantly with $100 \% \mathrm{RDF}+$ Azotobacter + PSB or $50 \%$ $\mathrm{RDF}+5 \mathrm{t} \mathrm{FYM}+$ Azotobacter + PSB significantly Jakhar et al., (2018). Jadhao et al., (2019) also reported an improvement in the organic carbon status of the soil with conjoint use of organics and fertilizers. Ravankar et al., (2005) reported that the maximum amount of organic carbon was found in the plot receiving inorganic fertilizers in combination with organics. In spite of regular application of organics in the vertisols of semi arid areas the organic carbon increase is gradual, therefore offers a great challenge for the substance of soil quality (Singh and Wanjari, 2007). Organic carbon content in soil increased significantly by supplementing fertilizers with organic sources (Singh et al., 2018). Report a field experiment conducted on a sandy loam soil at Varanasi, Uttar Pradesh. Integrated use of recommended level of NPK to pearl millet 
and mustard with organic manure and bio fertilizers improved the soil status of $\mathrm{N}$ and $\mathrm{P}$ by 83.0 and $26.3 \mathrm{~kg} \mathrm{ha}^{-1}$ over the initial value (Tomar et al., 2018).

Integrated use of bio-organics and inorganic fertilizers can improve crop productivity and sustain soil health $\&$ fertility and soil organic carbon. Irrespective of treatments soil health status with respect to soil organic carbon, $\mathrm{N}$, $\mathrm{P}$ and $\mathrm{K}$ has been improved in organic, inorganic and biological treated combined application to sole inorganic sources (Roy et al., 2017).

The improved organic matter content of soil in the treatment receiving organic material with chemical fertilizers might be owing to direct addition of organic substances in soil, better root growth and more plant residue recycled in soil (Sharma et al., 2000). The subsequent decomposition of these roots has resulted in increase organic carbon content soil (Tolanur and Badnur, 2003). The important in nutrient status of soil may be ascribed to more biomass (leaves and roots etc.) added by the pigeon pea (Shivran and Ahlawat, 2000). Application of organic nutrient sources with inorganic fertilizers over 31 years resulted in a significant income in SOC contents the initial status.

The maximum build up of SOC was observed in treatment applied with $50 \%$ RDF through fertilizers $+50 \% \mathrm{~N}$ as azola (Mishra et al., 2017). The increase in SOC due to integrated use of inorganic and organics can be attributed to higher contribution of biomass to the soil in the form of better root growth, crop residue and the added organic sources (Upadhyay and Vishwakarma, 2014). The higher build up of SOC in the organic sources applied plot may be attributed to slower break down rate and increased above and below ground organic residue due to enhanced crop growth (Moharana et al., 2012).

\section{Macro nutrients}

\section{Available nitrogen}

Incorporation of FYM along with fertilizers enhanced the available $\mathrm{N}$ content in post harvest soil as compared to control. Increase in available $\mathrm{N}$ may be attributed to mineralization of FYM (Chandel et al., 2014). There was a significant build up of available $\mathrm{N}$ in soil receiving $100 \%$ NPK along with FYM @ $10 \mathrm{t} \mathrm{ha}^{-1}$ over other treatment. This may be due to optimal fertilizers input (Chesti et al., 2015). Verma et al., (2012) reported that the balanced use of fertilizers alone or conjoint use of inorganics with organics resulted in a significant build up of available $\mathrm{N}$ over three decades leading to sustained soil fertility. The favourable soil conditions under organic manure application might have helped the mineralization of soil $\mathrm{N}$ leading to build up of higher available N (Walia et al., 2010).

Sharma et al., (2013) observed that availability $\mathrm{N}$ content in soil increased with the use of recommended dose of fertilizer in combination with manure. Pandey et al., (2009) reported that there was a build up of available $\mathrm{N}$ with conjoint use of chemical fertilizers with compost and crop residue incorporation in soil.

A significant improvement in available $\mathrm{N}$ status of soil with addition of crop residue and FYM was also reported by Sharma et al., 2000. Bajpai et al., (2006) observed that available $\mathrm{N}$ status of soil differ significantly with in situ incorporation of Sesbania aculeate, FYM and rice straw combined with chemical fertilizers over control. The build up of available $\mathrm{N}$ in soil due to application of NPK with or without organic manure may be ascribed to the residual effect of applied fertilizers and the mineralization of FYM (Bharambe et al., 2004). 
Application of crop residues along with FYM and green manure significantly increased the available N content of soil over $100 \%$ NPK alone (Kumar et al., 2008). Such an increase in the content of available $\mathrm{N}$ due to addition of organic material and chemical fertilizers has also been reported by Jagtap et al., 2007. Improvement of soil physic-chemical properties with the application of organic manure along with chemical fertilizers leads to build up of soil available $\mathrm{N}$ status (Karmakar et al., 2011). Application of organic nutrient sources with organic fertilizers over 31 years resulted in a significant increase in soil available $\mathrm{N}$ over the initial status. The maximum build up of $\mathrm{N}$ was observed in treatment applied with $50 \%$ RDF through fertilizers $+50 \% \mathrm{~N}$ as azolla (Mishra et al., 2017). The results of the field experiment conducted at Water Management Research Station, Begopara, Nadia, West Bengal, India revealed that the available $\mathrm{N}$ content in soil was found to maintain the highest fertility status in the treatment receiving NPK + FYM $10 \mathrm{t} \mathrm{ha}^{-1}+\mathrm{Zn} 5 \mathrm{~kg} \mathrm{ha}^{-}$ ${ }^{1}$ (Sarkar et al., 2016).

Ahmad et al., (2018) reported that application of recommended dose of fertilizers + PSB + Rhizobium + FYM @ $3 \mathrm{t} \mathrm{ha}^{-1}+$ Harit- Varden @ $5 \mathrm{t} \mathrm{ha}^{-1}$ recorded significantly build up of available $\mathrm{N}$ content over RDF alone. Improvement in the availability of soil $\mathrm{N}$ with the conjoint use of organic and inorganic fertilizer was also reported by Jadhao et al., 2019. Conjoint use of chemical fertilizers along with FYM increased the available $\mathrm{N}$ status (317 kg ha $\left.{ }^{-1}\right)$. The favourable soil condition provided by FYM addition might have helped in mineralization of additional soil $\mathrm{N}$ leading to build up of higher available N (Santhy et al., 1998). Sarin et al., (1991) also reported that mineralization of $\mathrm{N}$ was higher with the addition of FYM. The plant biomass produced is a source of $\mathrm{C}$ and $\mathrm{N}$ in due course of time can be converted into plant available forms through the process of mineralization (Glendining and Powlson, 1995). Sharma and Gupta (1998) also reported that supplementing organics with inorganic $\mathrm{N}$ fertilizers enhanced the available $\mathrm{N}$ content of the soil due to hastened mineralization, one the requirement of $\mathrm{N}$ by microbes is met through inorganic $\mathrm{N}$. Available $\mathrm{N}$ increased in treatments receiving varying combination of FYM, paddy straw and azolla with RDF and the enhancement was from $254.2 \mathrm{~kg} \mathrm{ha}^{-1}$ (initial) to $285.8 \mathrm{~kg}$ $\mathrm{ha}^{-1}$. Increase in available $\mathrm{N}$ with organics is attributed to its direct addition through organics which has released on mineralization with time (Sharma and Subehia, 2014). Increase in available $\mathrm{N}$ with organics was due to increase in SOC and slow release of $\mathrm{N}$ from organics (Yadav et al., 2000).

\section{Available phosphorus}

Swarup and Yaduvanshi (2000) reported that there was significant improvement in available phosphorus status of soil with addition of crop residue and FYM. The build up of available phosphorus in the soil due to application of $100 \%$ NPK with or without FYM application may be ascribed to the residual effect of applied fertilizers and the mineralization of FYM (Bharambe and Tomar, 2004). Similar observations were also reported by Bajpai et al., 2006. Kumar et al., 2008 reported that the available P status of soil was higher under $100 \%$ NPK + FYM which was on par with $100 \%$ NPK + green manure and 50\% NPK + FYM treatment. Long term fertilizers experiment under ricewheat system observed that fertilizers treatment had significant influence on available soil phosphorus (Bhatt, 2012).

The integrated nutrient management treatment $50 \% \mathrm{~N}$ through FYM $+50 \%$ NPK through fertilizers recorded the highest available $\mathrm{P}$ content in soil (Sharma et al., 2014). Chesti et 
al., (2015) reported that incorporation of FYM along with $100 \%$ NPK recorded significantly higher available $\mathrm{P}$ as compared to all other treatments. The increased availability of available $P$ with organics could be ascribed their solubilising effect on the native insoluble $\mathrm{P}$ fractions through release of various organic acid, thus resulting into a significant improvement in available $\mathrm{P}$ status of soil (Urkurkar et al., 2010). Kundu et al., (2016) reported that long term manure application along with chemical fertilizers led to significantly higher value of soil available $\mathrm{P}$ compared to other fertilization treatment. It has been noticed that in calcareous soil $\mathrm{CO}_{2}$ production play a dominant role in entraining the phosphorus availability (Singh and Wanjari, 2007).

Kakraliya et al., (2017) reported that application of recommended dose of NPK along with vermi compost, FYM and Azotobacter significantly increased the available phosphorus status of soil. Integrated use of recommended level of NPK to pearl millet and mustard with organic manure and bio fertilizers improved the soil status of $\mathrm{P}$ by $26.3 \mathrm{~kg} \mathrm{ha}^{-1}$ over the initial value (Tomar et al., 2018). Jadhao et al., (2019) also opined that the availability of phosphorus was improved with conjoint use of organic and fertilizer. The application of NPK along with FYM maintained $\mathrm{P}$ reserve fairly at high level which was $77.8 \%$ more optimal NPK. The FYM could have solubilised the native $P$ in the soil through the release of various organic acid (Jadhao et al., 2019). It has been noticed that in calcareous soil $\mathrm{CO}_{2}$ production play a dominant role in enhancing the $\mathrm{P}$ availability (Singh and Wanjari, 2007). Organic matter forms a protective cover on sesquioxide and this facilitate reduction in P-fixing capacity of soil (Tandon, 1987). The $\mathrm{P}$ build up under $100 \%$ NPK + 5 t FYM was higher which may be due to the influence of organic manure in increasing the labile pool in soil through completion of cations like $\mathrm{Ca}^{2+}$ and $\mathrm{Mg}^{2+}$ which as mainly responsible for the fixation of $\mathrm{P}$ in calcareous soil (Yashpal et al., 1993). Enhanced available pool of soil $\mathrm{P}$ with the application of inorganic fertilizers in conjunction with organics might be due to release of organic acid during decomposition which in turn helped in releasing $\mathrm{P}$ through solubilising native $\mathrm{P}$ in soil (Subehia and Sepehya, 2012).

\section{Available potassium}

There was a build up of available potassium in soil with conjoint use of chemical fertilizers with organics (Pandey and Kumar, 2018). Higher value of available $K$ in the treatment receiving chemical fertilizers, crop residue and compost may be due to higher organic matter content which retained available $\mathrm{K}^{+}$on exchange site (Kumari et al., 2017). The status of available $K$ declined in almost all the treatments except $100 \%$ NPK + FYM @ $10 \mathrm{t} \mathrm{ha}^{-1}$ as compared to initial status. The increase in available potassium under irrigated treatment might be due to addition of organic matter that reduce $\mathrm{K}$ fixation and released $\mathrm{K}$ due to interaction of organic matter with clay (Chesti et al., 2015).

Singh et al., (2006) reported that available K status of soil increased with the application of organic manure viz., FYM, rice straw, dhaincha and chemical fertilizer individually or in combination by $180-660 \mathrm{~kg} \mathrm{ha}^{-1}$ after rice and $25.1-78.4 \mathrm{~kg} \mathrm{ha}^{-1}$ after wheat. Kumar et al., (2008) reported that the crop residue incorporation along with $100 \%$ NPK increased the available $\mathrm{K}$ status by $10.6 \%$ over its initial status of $123 \mathrm{~kg} \mathrm{ha}^{-1}$. Significantly higher potassium content was recorded in the FYM and 100\% RDF treated plot over five year (Sushma et al., 2007). Sur et al., (2010) conducted a field experiment in a Haplaquept soil to study the effect of integrated nutrient management on 
availability of potassium in soil and reported that in general the adoption of integrated nutrient management practices helped to build up soil potassium status.

Enhancement of $\mathrm{K}$ content in soil with the adoption of integrated nutrient management has also been reported by Singh et al., 2011. Increase availability of K with $100 \%$ NPK + FYM application might be due to the direct addition of $\mathrm{K}$ to the available pool of the soil, mineralization of organic sources and solubilization from native source during the decomposition (Subehia and Sepehya, 2012). Kundu et al., 2016 reported that long term manure application along with chemical fertilizers led to significant higher values of soil available potassium. Improvement in available $\mathrm{K}$ status of soil with the integrated use of organics and inorganics fertilizers was also reported by Jadhao et al., 2019.

The increase in the status of available $\mathrm{K}$ with the combined use of organic and inorganic fertilizer at compared to even optimal or super optimal dose of NPK may be due to the addition organic minerals which supplies nutrient to the soil (Verma and Ram, 1994). Highest amount of available $\mathrm{K}$ in the FYM treated plots may be due to the fact FYM addition could increase the CEC of soil, which is responsible for holding more amount of exchangeable $\mathrm{K}$ and helped in the release of exchangeable $\mathrm{K}$ from non-exchangeable $\mathrm{K}$ pool (Kher and Minhas, 1991). This may also ascribed to the reduction in the $\mathrm{K}$ fixation and release of $\mathrm{K}$ from non-exchangeable site of the reserve held in the clay inter layers. The highest status of available $\mathrm{K}$ in $150 \%$ NPK over rest of the treatments may be due to higher rate (Sood et al., 2008). Application of inorganic fertilizer alone or in combination with organic nutrient sources recorded an increase in available $\mathrm{K}$ of the soil over control (Mishra et al., 2017). Highest available K under integrated treatments compared to inorganics might be due to addition of organic matter that reduced $\mathrm{K}$-fixation and released $\mathrm{K}$ due to interaction of organic matter with clay, besides the direct $\mathrm{K}$ addition to the pools of soil (Urkurkar et al., 2010).

\section{Available sulphur, calcium and magnesium}

The studies on long term influence of four fertility levels and organic \& inorganic sulphur under rice-wheat cropping system on soil fertility build up revealed a significant increase in available sulphur content in soil (Kumar et al., 2011). Maximum available (35-39 $\mathrm{mg} \mathrm{kg}^{-1}$ ) was noticed when $150 \%$ NPK of the recommended dose was applied in conjuction with compost and crop residue and the might be due to addition of S through SSP and mineralization of organic S (Pandey and Kumar, 2018). Chandel et al., (2014) reported that under wheat-maize cropping sequence combined application of $150 \mathrm{~kg} \mathrm{~N}+10 \mathrm{t}$ FYM ha ${ }^{-1}$ was found to be beneficial in increasing the productivity of the crop and improving available $\mathrm{S}$ status of the soil as compared to sole application of fertilizers. Adoption of integrated nutrient practices helped to build up $\mathrm{Fe}, \mathrm{Mn}$ and $\mathrm{Cu}$ content.

Sushma et al., (2007) reported that sulphur content was significantly higher in coir pith based compost with pressmud and $100 \%$ RDF treated plots. The effect of crop residues on $S$ availability in soil was enhanced in the presence of FYM or green manure (Kumar et al., 2008). The improvement in the status of available sulphur with application of NPK (where SSP was used) + 5 t FYM is obvious apparently due to supply of $S$ through chemical fertilizers and organic sources (Jadhao et al., 2019). The available calcium and magnesium was found superior when applied with organic and inorganic fertilizers. The highest value was recorded in the treatment receiving vermicompost @ $5 \mathrm{t} \mathrm{ha}^{-1}$ with $75 \%$ RDF and it was followed by 
application of sewage sludge @ $2 \mathrm{tha}^{-1}$ with 75\% RDF and green manure@12.5 t ha ${ }^{-1}$ with 75\% RDF (Sanjivkumar, 2014). The increase in available $S$ was due to use of single superphosphate (SSP) as a source of P, which contains appreciable amount of S. The improvement in the status of available $\mathrm{S}$ with the application of NPK (where SSP was used) +5 t FYM is obvious apparently due to supply of $\mathrm{S}$ through chemical fertilizer and organic sources (Jadhao et al., 2019). Continuous cropping with $100 \%$ NPK (-S) resulted in drastic reduction in available $S$ (10.86 $\mathrm{mg} \mathrm{S} \mathrm{kg}^{-1}$ ) which may be attributed to continuous use of DAP as $\mathrm{P}$ source which resulted in S deficiency in 100\% NPK (-S) treatment causing reduction in crop yield (Santhy et al., 1998). The available $\mathrm{Ca}$ and $\mathrm{Mg}$ were found superior when applied with organic and inorganic fertilizers. The highest value was recorded in the treatment receiving vermicompost@ $5 \mathrm{t} \mathrm{ha}^{-1}$ with 75\% RDF and green manure@12.5 t ha ${ }^{-1}$ with 75\% RDF. The increase in exchangeable $\mathrm{Ca}$ and $\mathrm{Mg}$ content of soil might be due to release of these nutrients from added organic sources (Sanjivkumar, 2014)

\section{Micronutrient}

\section{Zinc (Zn)}

Chandel et al., (2014) concluded that under wheat-maize cropping sequence combined application of $150 \mathrm{~kg} \mathrm{~N}+10 \mathrm{t} \mathrm{FYM} \mathrm{ha}^{-1}$ was found to be beneficial in increasing the availability of $\mathrm{Zn}$ status in the soil by $0.12 \mathrm{mg}$ $\mathrm{kg}^{-1}$, respectively as compared to sole application of fertilizers. The reason of higher $\mathrm{Zn}$ content in the soil with FYM was that FYM improved the availability of both native and added $\mathrm{Zn}$ through transformation of solid phase to soluble metal complex (Latha et al., 2001). Report of a field experiment conducted on a sandy loam at Varanasi, Uttar Pradesh to study the direct effect of three sources of organic manure i.e. sewage, sludge, vermicompost and Sesbania green manure in combination with recommended dose of NPK, reveals a differential pattern of nutrient build up as $\mathrm{Zn}$ in post harvest soil (Singh et al., 2018). Zinc is known to form relatively stable chelates with organic legends which decrease the susceptibility to adsorption fixation and precipitation (Subehia et al., 2011).

Prasad et al., (1980) reported that continuous use of chemical fertilizers singly or in combination with FYM increased or maintained the initial status of micro nutrients. Bellaki et al., (1998) conducted a long term field experiment for 10 years and reported that the combined experimentation of organic and inorganic sources of nutrients increased the available micronutrients significantly in comparison to inorganic fertilizers alone. Sushma et al., (2007) reported that application of coir pith based compost $\left(45 \mathrm{t} \mathrm{ha}^{-1}\right)$ and $100 \%$ RDF recorded the highest $\mathrm{Zn}$ content of $0.74 \mathrm{mg} \mathrm{kg}$. [Addition of organic material might have enhance the microbial activity in the soil and the consequent release of complex organic substances would have presented micronutrients from precipitation, fixation and leaching. Incorporation of compost, crop residues either alone or in combination with chemical fertilizers increases the available $\mathrm{Zn}$ status of soil over control (Pandey and Kumar, 2018). Jadhao et al., (2019) also reported an enhancement of soil available $\mathrm{Zn}$ status with incorporation of organics in conjunction with inorganic fertilizers.

Continuous cropping with $100 \%$ NPK $+\mathrm{Zn}$ resulted in the build up of DTPA-Zn which is obvious, however, the increase in available $\mathrm{Zn}$ status with the application of NPK $+5 \mathrm{t}$ FYM and FYM alone may be due to mineralization of organically bound form of $\mathrm{Zn}$ with organics (Jadhao et al., 2019). 
Kakraliya et al., (2017) reported that application of recommended due to NPK along with vermicompost, FYM and Azotobacter significantly increased the available nitrogen, phosphorus and potash status of soil. Similar results were also confirmed by Singh et al., 2015 where NPK, FYM and bio fertilizer significantly increased the available N, P and K content over control. Pandey et al., (2009) also reported that addition of organic manure with fertilizers level significantly improved the organic carbon content as compared to chemical fertilizer alone.

Zinc is known to form relatively stable chelates with organic legends which decrease their susceptibility to adsorption fixation and precipitation (Subehia et al., 2011). Amount of nutrient added, reaction time in soil, rate of extraction by roots, nature and amounts of clay minerals, organic matter content are the governing factors affecting the transformation of $\mathrm{Zn}$ in soil. (Jat et al., 2014).

\section{Boron (B)}

Chander et al., (2007) reported that incorporation of FYM in the experimental soil, maintained a higher availability of boron. The availability of B decrease significantly with increasing levels of chemical fertilizers and incorporation of compost and crop residue alone or in combination significantly increased the soil available $B$ and the effectiveness followed the order compost + crop residue $>$ compost $>$ crop residue $>$ control (Pandey and Kumar, 2018).

Parmer (2014) reported that the increased the status of available $B$ with addition of boron fertilizers may be due to the increased availability of B in the soil. The formation of chelates with organic legends due to addition of FYM resulting higher B availability in soil.
The amount of all cationic micronutrients (Fe, $\mathrm{Mn}, \mathrm{Cu}$ and $\mathrm{Zn}$ ) was progressively higher with the crop growth period suggesting a build up of these micronutrients in soil resulting from the adoption of integrated nutrient management system. Such build up of micronutrient might be partially owing to release of native soil micronutrient resulting from the dissolution action of organic manure (Sur et al., 2010).

\section{Copper $(\mathbf{C u})$}

Numerically highest copper content was observed in the treatment having FYM @ $10 \mathrm{t}$ $\mathrm{ha}^{-1}+100 \%$ RDF followed by treatment receiving FYM @ $10 \mathrm{t} \mathrm{ha}^{-1}+50 \% \mathrm{RDF}$ (Prashanath et al., 2019). Sur et al., (2010) reported that integrated nutrient management system has positive effect in build up of soil available $\mathrm{Cu}$ status. Use of FYM, wheat straw and green manure along with chemical fertilizers significantly superior over alone and or recommended dose of chemical fertilizer application (Kumari et al., 2017).

\section{Iron $(\mathbf{F e})$}

Among the long term fertilizers treatment receiving FYM @ $10 \mathrm{t} \mathrm{ha}^{-1}+100 \%$ RDF numerically recorded higher iron content Prashanath et al., (2019). Chaudhary and Narwal (2005) reported that the application of FYM significantly increased the DTPA extractable Fe status of soil. Under long term fertilization the available iron content increased even through land was continuously cropped indicated that considerable quantity of iron being added to the soil every year through application of fertilizers or due to increase the $\mathrm{H}^{+}$activity on fertilizers application (Sarkar, 1990). Sur et al., (2010) reported that build up of available Fe through integrated nutrient management system might be due to release of soil native Fe. Kumari et al., (2017) reported that highest DTPA 
extractable content was recorded in the treatment with the application of $50 \%$ mineral fertilizers supplemented with $50 \% \mathrm{~N}$ through FYM as compared to control.

\section{Manganese (Mn)}

The treatment receiving FYM @ $10 \mathrm{t} \mathrm{ha}^{-1}+$ $100 \%$ RDF recorded highest manganese content of 18.50 and $18.53 \mathrm{mg} \mathrm{kg}-1$. (before sowing and at harvest, respectively) in soil. The DTPA extractable Mn declined from their respective initial values as a result of continuous cropping and fertilizers application in control and also with imbalanced fertilization (Prashanath et al., 2019). This is essential to the continuous uptake by the crops over the year in addition to their non-replenishment in the form of fertilizers (Sanjib et al., 2009). Chaudhary and Narwal (2005) reported that application of FYM significantly increased the DTPA extractable Mn. The amount of $\mathrm{Mn}$ was progressively higher with the crop growth period suggesting a build up of this micronutrient in soil, resulting from the adoption of integrated nutrient management system (Sur et al., 2010). Significantly, higher available micronutrient values were recorded in the treatment receiving FYM along with balanced fertilizers compared to no FYM treatment (Hemalatha and Chellamuthu, 2012). Enhancement of Mn status of soil with the application of FYM, wheat straw and green manure with RDF is also reported by Kumari et al., 2017.

\section{References}

Ahmad, A., Kumar, N. and Yadav, D. (2018). Integrated nutrient management in pigeon pea based intercropping systems. Indian Journal of Agronomy 63(1): 3944.

Babhublkar, P. S., Wandile, R. M., Badole, W. P. and Balpande, S. S. (2000).
Residual effect of long-term application of FYM and fertilizers on soil properties (Vertisol) and yield of soybean. Journal of the Indian Society of Soil Science 48(1): 89-92.

Bajpai, R. K., Chitale, S., Upadhyay, S. K. and Urkurkar, J. S. (2006). Long-term studies on soil physico-chemical properties and productivity of ricewheat system as influenced by integrated nutrient management in Inceptisol of Chhattisgarh. Journal of the Indian Society of Soil Science 54(1): 24-29.

Bellaki, M. A., Badanur, V. P. and Setty, R. A. (1998). Effect of long-term integrated nutrient management on some important properties of a vertisol. Journal of the Indian Society of Soil Science 46(2): 176-180.

Beri, V., Sidhu, B. S., Bahl, G. S. and Bhat, A. K. (1995). Nitrogen and phosphorus transformations as affected by crop residue management practices and their influence on crop yield. Soil Use and Management 11(2): 51-54.

Bharambe A. P. and Tomar, A. (2004). Direct and residual effect of FYM and inorganic nutrients on rice-wheat cropping system in vertisol. $P K V$ Research Journal 28: 47-52.

Bharambe, P. R., Patil, V. V., Shelke, D. K., Oza, S. R. and Sondge, V. D. (2004). Response of Rabi groundnut to phosphorus levels under different land layouts and moisture regimes grown on vertisol. Journal of the Indian Society of Soil Science 52(3): 262-265.

Bhatt B. (2012). Effect of long term fertilizer application in rice-wheat system on crop productivity and soil. $\mathrm{Ph}$. D. Thesis submitted to G.B.P.U.A. \& T., Pantnagar, India, 135-145.

Chandel, B. S., Singh, S., Singh, H. and Singh, V. (2014). Direct and residual effect of nutrient management in wheat 
maize cropping sequence. Journal of the Indian Society of Soil Science 62(2): 126-130.

Chander, Girish; Verma, T. S. and Sharma, Sandeep (2007). Influence of boron and farmyard manure on available boron and exchangeable calcium and their removal by cauliflower in the borondeficient soils of Himachal Pradesh. Journal of the Indian Society of Soil Science 55(1): 62-66.

Chaudhary, M. and Narwal, R. P. (2005). Effect of long term application of FYM on soil micronutrient status. Archives of Agronomy and Soil Science 51: 351359.

Chesti, M. H., Kohli, A., Aziz, M., Safi, J. A., Quadin, N. T., Peer, Q. J. A., Dar, M. A. and Bisati, J. A. (2015). Effect of integrated application of inorganic and organic sources on soil properties, yield and nutrient uptake of rice in Intermediate zone of Jammu and Kashmir. Journal of the Indian Society of Soil Science 63(1): 88-92.

Gathala, M. K., Kanthaliya, P. C., Verma, A. and Chahar, M. S. (2007). Effect of integrated nutrient management on soil properties and humus fractions in the long-term fertilizer experiments. Journal of the Indian Society of Soil Science 55(3): 360-363.

Glendining, M. J. and Powlson, D. S. (1995). The effects of long continued applications of inorganic fertilizers on soil organic nitrogen - A review. In Soil Management: Experimental Basis for Sustainability and Environmental Quality. Advances in Soil Science (R. Lal and B.A. Stewart, Eds.), Lewis Publishers, CRC Press, Inc. Boca Raton, Florida, pp. 385-446.

Hemalatha, S. and Chellamuthu, S. (2012). Impact of long term fertilization on soil nutritional quality under finger milletmaize cropping sequence. Journal of
Environment Research Development 7(4): 1571-1576.

Jadhao, S. D., Mali, D. V., Kharche, V.K., Singh, Muneshwar; Bhoyar, S. M., Kadu, P. R., Wanjari, R. H. and Sonune, B. A. (2019). Impact of Continuous Manuring and Fertilization on Changes in Soil Quality under Sorghum-Wheat Sequence on a Vertisols. Journal of the Indian Society of Soil Science 67(1): 5564.

Jagtap, P. B., Patil, J. D., Nimbalkar, C. A. and Kadlag, A. D. (2007). Influence of integrated nutrient management on soil properties and release of nutrients in a saline-sodic soil. Journal of the Indian Society of Soil Science 55(2): 147-156.

Jakhar, R. R., Shekhawat, P. S., Yadav, R. S., Kumawat, B. A. and Singh, A. P. (2018). Integrated nutrient management in pearl millet in north-western Rajasthan. Journal Name 63(2): 192196.

Jat, Gajanand; Majumdar, S. P., Jat, N. K. and Mazumdar, Sonali P. (2014). Effect of potassium and zinc fertilizer on crop yield, nutrient uptake and distribution of potassium and zinc fractions in Typic Ustipsamment. Indian Journal of Agricultural Sciences 84(7): 832-838.

Kakraliya, S. K., Jat, R. D., Kumar, S., Chaudhary, J. P. and Singh, L. K. (2017). Integrated nutrient management for improving, fertilizers use efficiency, soil biodiversity and productivity of wheat in irrigated rice-wheat cropping system in Indo-Gangetic plains in India. International Journal of Current Microbiology and Applied Sciences 6(3): 152-163.

Karmakar, S., Prakash, Surya; Kumar, Rakesh; Agrawal, B. K., Prasad, Devkant and Kumar, Rajeev (2011). Horizon of a Vertisol of Central India after 28 Years of Continuous Cropping, Fertilization and Manuring. Agriculture, 
Ecosystems and Environment 119(1-2): 127-134.

Karmakar. S., Prakash, S., Kumar, R., Agrawal, B. K., Prasad, D. and Kumar, R. (2011). Effect of green manuring and biofertilizers on rice production. Oryza 48(4): 339-342.

Kher, D. and Minhas, R. S. (1991) Effect of continuous liming, manuring and cropping on different forms of soil acidity in an Alfisol. Journal of the Indian Society of Soil Science 39: 169171.

Kumar, A. and Yadav, Y. S. (2003). Use of organic manures and fertiliser in rice (Oryza sativa)-wheat (Triticum aestivum) cropping system for sustainability. Indian Journal of Agricultural Science 65(10): 703-707.

Kumar, Balwinder; Gupta, R. K. and Bhandari, A. L. (2008). Soil fertility changes after long term application of organic manures and crop residues under rice-wheat system. Journal of the Indian Society of Soil Science 56(1): 8085.

Kumar, V., Pandey, A. K., Prasad, R. K. and Prasad, B. (2011). Long term influence of organic and inorganic sulphur and fertility levels on yields, distribution and build up of $\mathrm{S}$ under rice-wheat cropping system in Calciorthents. Journal of the Indian Society of Soil Science 59(3): 278-282.

Kumari, G., Thakur, S. K., Kumar, N. and Mishra, B. (2013). Long term effect of fertilizers, manure and lime on yield sustainability and soil organic carbon status under maize (Zea mays) -wheat (Triticum aestivum) cropping system in Alfisols. Indian Journal of Agronomy 58(2): 152-158.

Kumari, Madhavi; Pandey, Amit Kumar and Singh, Ashutosh (2017). Effect of continuous cropping and fertilization on distribution of potassium fractions under rice-wheat cropping system in Calciorthents. Chemical Science Review and Letters 6(24): 253-2359.

Kumari, Richa; Kumar, Sunil; Kumar Rajkishore, Das, Anupam; Kumari, Ragini; Choudhary, C. D. and Sharma, R. P. (2017). Effect of long - term integrated nutrient management on crop yield, nutrition and soil fertility under rice-wheat system. Journal of Applied and Natural Science 9(3): 1801 - 1807.

Kundu, D. K., Mazumadar, S. P., Ghosh, D., Saha, A. R., Majumdar, B., Gorai, A. K. and Behra, M. S. (2016). Long term effect of fertilizers and manure application on soil quality and sustainability of Jute-rice-wheat production system in Indo-Gangetic plain. Journal of Applied and natural Science 8(4): 1793-1800.

Lalith Kannan, R., Dhivya, M., Abinaya, D., Lekshmi Krishna, R. and Krishnakumar, S. (2013). Effect of integrated nutrient management on soil fertility and productivity in maize. Bulletin of Environment, Pharmacology and Life Science 2(8): 61-67.

Latha, M. R., Savithri, P., Indrani, R. and Kamraj, S. (2001). Influence of $\mathrm{Zn}$ enriched organic manure on the yield, dry matter production and zinc uptake of maize. Acta Agronomica Hungarica 49: 231-236.

Mishra, K. N., Patra, A. K., Garnayak, L. M., Mohanty, A. K. and Swain, S. K. (2017). Long term effects of integrated nutrient management on productivity and soil properties of rice-wheat cropping system in coastal Odisha. Indian Journal of Agronomy 62(3): 239246.

Moharana, P. C., Sharma, B. M., Biswas, D. R., Dwivedi, B. S. and Singh, R. V. 2012. Long-term effect of nutrient management on soil fertility and soil organic carbon pools under a 6-yearold 
pearlmillet-wheat cropping system in an Inceptisol of subtropical India. Field Crops Research 136: 32-41.

Nambiar, K. K. M. (1985). All India Coordinated Research project on longterm fertilizer experiments and its research achievements. Fertilizer News 30(4): 56-66.

Nayak, A. K. and Mohan, U. (2012). Long term effect of different integrated nutrient management on soil organic carbon and its fractions and sustainability of rice-wheat system in Indo-Gangetic Plains of India. Field Crop Research 127(27): 129-139.

Pandey, A. K. and Kumar, V. (2018). Long term effect of organics and inorganics fertilizers on yield, uptake and nutrition of sulphur, zinc and boron in calcareous soil. International Journal of Current Microbiology and Applied Sciences Special Issue 7: 5048-5057.

Pandey, I. B., Dwivedi, D. K. and Pandey, R. K. (2009). Integrated nutrient management for sustaining wheat production under late sown condition. Indian Journal of Agronomy 54(3): 306309.

Pandey, K. K. and Awasthi, A. (2014). Integrated nutrient management in the maize (Zea mays L.) yield and soil properties. International Journal of Agricultural Sciences 10(1): 244-246.

Parmer, D. K. (2014). Yield, produce quality and soil health under vegetable cropping system as influenced by integrated nutrient management in mid hill zone of Himachal Pradesh. Journal of the Indian Society of Soil Science 62(1): 45-51.

Patra, A. K., Mishra, K. N., Garnayak, L. M. and Mohanty, A. K. (2017). Influence of long term organic nutrient management on soil quality and crop productivity in rice-potato-okra cropping system under irrigated condition. Indian Journal of Agronomy 62(3): 268-274.

Phogat, S. B., Dahiya, I. S., Hooda, R. S., Sangwan, N. K. and Solanki, Y. P. S. (2004). Studies on residual effect of green manuring and farm yard manure for sustained productivity of rice wheat cropping sequence and on soil health under shallow ground water table condition. Annals of Biology 20(2): 161165.

Prasad, B., Singh, R. P. and Singh, H. (1980). Accumulation and Decline of Micronutrient Elements with Long Term Use of Chemical Fertilizer, Lime and Manure in Multiple Cropping. Journal of the Indian Society of Soil Science 28(2): 263-264.

Prashanath, D. V., Krishnamurthy, R., Naveen, D. V., Mudalagiriyappa and Boraiah, B. (2019). Long term effect of integrated nutrient management in soil micronutrient status in finger millet mono-cropping system. Indian Journal of Pure Applied Bioscience 7(4): 152159.

Ravankar, H. N., Gajbhiye, N. N. and Sarap, P. A. (2005). Effect of organic manure and inorganic fertilizer on yield and availability of nutrient under sorghum wheat sequence. Indian Journal of Agricultural Research 39(2): 142-145.

Roy, M. D., Sarkar, G. K., Das, J. Karmakar and Saha, T. (2017). Integrated use of inorganic, biological and organic manure on rice productivity, nitrogen uptake and soil health in Gangetic alluvial soils of West Bengal. Journal of the Indian Society of Soil Science 65(1):72-79.

Sanjib Kumar, B., Singh, D. and Brahma Swaroop, D. (2009). Changes in fractions of iron, manganese, copper and zinc in soil under continuous cropping for more than three decades. Commun. Soil Sci. Pl. Anal., 40(9-10): 
1380- 1407.

Sanjivkumar, V. (2014). Effect of integrated nutrient management on soil fertility and yield of maize crop (Zea mays) in Entic Haplustart in Tamil Nadu, India. Journal of Applied and Natural Science 6(1): 294-297.

Santhy, P., Muthuvel, P., Murugappan, V. and Selvi, D. (1998). Long-term effects of continuous cropping and fertilization on crop yields and soil fertility status. Journal of the Indian Society of Soil Science 46: 391- 395.

Sarin, T., Tanaka, Y. and Kitagawa (1991). Utilization of organic matter for vegetable cultivation under a paddy upland rotation system. Nara Agricultural Experiment Station 22: 5764.

Sarkar, M. C. (1990). Long term effect of fertilizers on soil eco system. Fertilizer News 35: 81-85.

Sarkar, S., Das, D. K. and Dolui, D. K. (2016). Effect of integrated nutrient management on soil fertility and yield of rice (Oryza sativa L.) under the system of rice intensification in the Indian subtropics. Communication in Soil Science and Plant Analysis 47(18): 2053-2058.

Sharma, J. D., Thakur, R., Raj, S., Kumar, D. L. and Kulhare, P. S. (2013). Nutrient uptake, protein content of wheat and soil fertility in a Typic Haplustert. The Bioscience 8(4): 1159-1164.

Sharma, M. P. and Bali, S. V. (2000). Longterm effect of different cropping systems on physico-chemical properties and soil fertility. Journal of the Indian Society of Soil Science 48(1): 181-183.

Sharma, M. P. and Gupta, J. P. (1998). Effect of organic materials on grain yield and soil properties in maize (Zea mays) wheat (Triticum aestivum) cropping system. Indian Journal of Agricultural Sciences 68(11): 715-717.
Sharma, M. P., Bali, S. V. and Gupta, D. K. (2000). Crop yield and properties of inceptisol as influenced by residue management under rice - wheat cropping sequence. Journal of the Indian Society of Soil Science 48(3): 506- 509.

Sharma, R. P., Kaushal, V., Verma, G. and Sharma, S. P. (2014). Effect of three decade long application of chemical fertilizer and amendments on crop yield under maize - wheat cropping system in an acid alfisol. Journal of Applied and Natural Science 6(1): 106-109.

Sharma, S. P. and Subehia, S. K. (2003). Integrated long-term effects of chemical fertilizers on crops yields, nutrients uptake and soil environment in western Himalayan soils. (In): Long-term soil fertility management through integrated plant nutrient supply (Swarup, A., Reddy, D.D. and Prasad, R.N. eds.) IISS, Bhopal, India, pp.125-138.

Sharma, U. and Subehia, S. K. (2014). Effect of long term integrated nutrient management of rice (Oryza sativa L.) wheat (Triticum aestivum L.) on productivity and soil properties in North-Western Himalaya. Journal of the Indian Society of Soil Science 62(3): 248-254.

Shivran, D. R. and Ahlawat, I. P. S. (2000). Crop productivity, nutrient uptake and soil fertility as influenced by cropping system and fertilizers in pigeonpea (Cajanus cajan)-wheat (Triticum aestivum) cropping system. Indian Journal of Agricultural Sciences 70(12): 815-819.

Singh, D. and Nepalia, V. (2009). Influence of integrated nutrient management on quality protein maize (Zea mays) productivity and soils of southern Rajasthan. Indian Journal of Agricultural Sciences 79(12): 1020-22.

Singh, G. B. and Swarup, P. (2000). Lessons 
from long-term fertility experiments. Fertilizer News 45: 13-18 and 21-24.

Singh, G. D., Vyas, A. K. and Dhar, S. (2015). Productivity and profitability of wheat based cropping system under different nutrient management practices. Indian Journal of Agronomy 60(1): 5256.

Singh, Muneshwar and Wanjari, R. H. (2007). Research bulletin on lessons learnt from long-term fertilizer experiments and measures to sustain productivity in Alfisols. AICRP on LTFE to study changes in soil quality, crop productivity and sustainability, Indian Institute of Soil Science, Bhopal p. 118.

Singh, N. P., Sachan, R. S., Pandey, P. C. and Bisht, P. S. (1999). Effect of a decade long- term fertilizer and manure application on fertility and productivity of rice-wheat system in a mollisols. Journal of the Indian Society of Soil Science 47(1): 72-80.

Singh, R. N., Singh, Surendra; Prasad, S. S. and Singh, V. K. (2011). Effect of integrated nutrient management on soil fertility, nutrient uptake and yield of rice-pea cropping system on an upland acid soil of Jharkhand. Journal of the Indian Society of Soil Science 59(2): 158-163.

Singh, Satish Kumar; Kumar, Maneesh; Singh, Ravi P. and Bohra, Jitendra Singh (2018). Conjoint Application of Organic and Inorganic Sources of Nutrients on Yield, Nutrient Uptake and Soil Fertility under Rice (Oryza sativa)Wheat (Triticum aestivum) System. Journal of the Indian Society of Soil Science 66(3): 287-294.

Singh, Surendra; Singh, R.

N., Prasad, Janardan and Singh, B. P. (2006). Effect of integrated nutrient management on yield and uptake of nutrients by rice and soil fertility in rainfed upland. Journal of the Indian Society of Soil Science 54(3): 327-330.

Sood, Bannu; Subehia, S. K. and Sharma, S. P. (2008). Potassium fraction in acid soil continuously fertilized with mineral fertilizers and amendments under maize-wheat cropping system. Journal of the Indian Society of Soil Science 56(1): 54-58.

Subehia, S. K., Dhanlkai and Rana, S. S. (2011). Effect of continuous cropping and fertilization on availability of nutrients in an acidic soil. Agropedology 21(1): 18-22.

Subehia, S. K. and Sepehya, Swapana (2012). Influence of long-term nitrogen substitution through organics on yield, uptake and available nutrients in a ricewheat system in an acidic soil. Journal of the Indian Society of Soil Science 60(3): 213-217.

Sur, P., Mondal, M. and Das, D. K. (2010). Effect of integrated nutrient on soil fertility and organic carbon in cabbage growing soil. Indian Journal of Agricultural Sciences 80(8): 695-698.

Sushma, A. R., Basavaraja, P. K., Badrinath, M. S. and Sridhara S. (2007). Residual effect of integrated nutrient management with coir pith compost and other organics on subsequent ragi crop yield and chemical properties of Vertisols. Journal of the Indian Society of Soil Science 455(4): 500-504.

Swarup, A. and Yaduvanshi, N.P.S. (2000). Effect of Integrated nutrient management on soil properties and yield of rice in Alkali soils. Journal of the Indian Society of Soil Science 48(2): $279-282$.

Tandon, H. L. S. (1987). Phosphorus Research and Agricultural Production in India. FDCO, New Delhi.

Tolanur, S. I. and Badanur, V. P. (2003). Effect of integrated use of organic manure, green manure and fertilizer 
nitrogen on sustaining productivity of Rabi sorghum-chickpea system and fertility of a vertisol. Journal of the Indian Society of Soil Science 51(1):4144.

Tomar, P. S., Verma, S. K., Gupta, Naresh and Bansal, K. N. (2018). Effect of long term integrated nutrient management on productivity of pearl millet- mustard cropping system and soil fertility in an Inceptisol. Journal of the Indian Society of Soil Science 66(3): 295-299.

Upadhyay, V. B. and Vishwakarma, S. K. (2014). Long-term effect of integrated nutrient management in rice (Oryza sativa)-wheat (Triticum aestivum) cropping system. Indian Journal of Agronomy 59(2): 209-214.

Urkurkar, J. S., Tiwan, A., Chilate, S. and Bajpai, R. K. (2010). Influence of long term use of inorganic and organic manure in soil fertility and sustainable productivity of rice and wheat in Inceptisols. Indian Journal of Agricultural Sciences 80(3): 208-212.

Verma, G., Sharma, R. P., Sharma, S. P., Subehia, S. K. and Shambhavi, S. (2012). Changes in soil fertility status of maize - wheat system due to long-term use of chemical fertilizers and amendments in an alfisol. Plant Soil Environment 58(12): 529-533.
Verma, R. K. and Ram, N. (1994). Effect of continuous cropping and fertilizer application on different forms of $\mathrm{K}$ in Mollisols. Journal of Potassium Research 10: 149-154.

Walia, M. K., Walia, S. S. and Dhaliwal, S. S. (2010). Long term effect of integrated nutrient management on properties of Typic Ustochrept after 23 cycle of an irrigated rice-wheat system. Journal of Sustainable Agriculture 34(7): 724-743.

Yadav, R. L., Dwivedi, B. S., Prasad, K., Tomar, O. K., Shurpali, N. J. and Pandey, P. S. (2000). Yield trends and changes in soil organic- $\mathrm{C}$ and available NPK in a long-term rice - wheat system under integrated use of manures and fertilizers. Field Crops Research 68: $219-246$.

Yaduvanshi, N. P. S. (2001). Effect of five years of rice-wheat cropping and NPK fertilizers use with and without organic and green manures on soil properties and crop yields in a reclaimed sodic soil. Journal of the Indian Society of Soil Science 49(4): 714-719.

Yashpal, Vig, A. C. and Chand, Milap (1993). Available soil phosphorus in relation to sesbania green manure incorporation in calcareous soil. Journal of the Indian Society of Soil Science 41(1): 47-50.

\section{How to cite this article:}

Amit Kumar Pandey, Ashutosh Singh and Umesh Singh. 2020. Influence of Integrated Nutrient Management Strategies on Soil Fertility. Int.J.Curr.Microbiol.App.Sci. 9(08): 2450-2465. doi: https://doi.org/10.20546/ijcmas.2020.908.280 